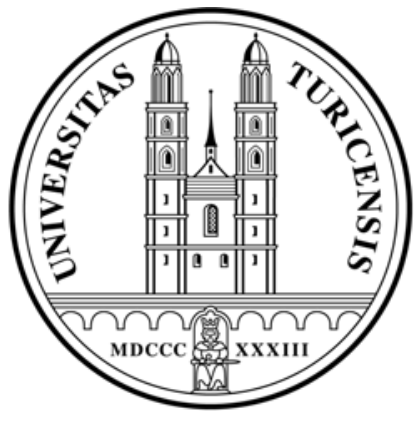

Institute for Empirical Research in Economics

University of Zurich

Working Paper Series

ISSN 1424-0459

Published in:

Journal of Institutional and Theoretical Economics (JITE), 157

(March 2001), S. 162 - 175

Working Paper No. 47

A Utopia? Government without Territorial Monopoly

Bruno S. Frey

June 2000 


\title{
A UTOPIA? \\ GOVERNMENT WITHOUT TERRITORIAL MONOPOLY
}

\author{
Bruno S. Frey*
}

\begin{abstract}
We normally take it for granted: a government or state has its corresponding territory. This paper shows that government need not have a territorial monopoly. The paper advances a practical, constitutional proposal, based on the notion that there are meaningful government units, whose major characteristic is not the terrritorial extension but ist function. The constitution proposal allows for the emergence of governmental organisations, which will be called FOCJ according to the acronym for "Functional, Overlapping, Competing Jurisdictions". Their territory is variable, and they do not have a territorial monopoly over it. Rather, they are in competition with other such FOCJ, and they are, moreover, exposed to political competition.
\end{abstract}

Keywords: federalism, constitutional economics, public choice, monopoly on territory

JEL classification: $\mathrm{H} 11, \mathrm{H} 4, \mathrm{H} 5$

\section{Relationships between Government and Territory}

We normally take it for granted: a government or state has its corresponding territory. The relationship is one to one. Each government has a particular territory, and each territory belongs to a particular government. Moreover, the relationship is clearly defined. There is no uncertainty which government rules over a particular territory, and each territory is unequivocally assigned to some government.

Yet this identification of government with territory need not be the case at all. There are important instances in which it does not hold:

(1) Multiple Governments Associated with the Same Territory 
The classical case is where several governments claim the same territory. Sometimes the borders are ill defined, sometimes the ownership is disputed, and has sometimes been for centuries. This has been the cause of innumerable wars in the history of mankind. Such wars often seem to be the result of a collective failure. The individual actors and groups involved - in particular the politicians playing the nationalist tune, the military-industrial complex - find it individually rational to fight for territories. But from the point of view of society, it is difficult to see what is really gained. This is easy to see for the governments engaging in a territorial war and losing it. But the same often holds also for the winners. They also spend valuable resources for military purposes, but in addition they would in may cases be better off not owning the conquered territory:

- Land is often unproductive and agriculture therefore has to be strongly subsidised, which puts a heavy burden on the economy and society. This can be well illustrated by the case of Germany. The Nazis urgently claimed for "Raum im Osten", trumpeting that the German population otherwise could not be nurtured. Look at Germany now. It has experienced a Wirtschaftswunder within a territory which was (even after the reunification), and still is, smaller than in 1933. Obviously, no additional territory was needed. It could even be argued that the Federal Republic would be better off if the Saar had decided to join France instead of Germany, because the Saar must be supported by large subsidies from the rest of Germany.

- It is often advantageous not to own territories populated by certain industries. This holds in particular for steel mills, or shipbuilding, which often have to be heavily subsidised. Thus it is preferable for the society as a whole not to own them.

- Even the existence of natural resources in a territory is not necessarily advantageous. Again, the extraction of some natural resources often has to be strongly subsidised, as in the case of coal. Owning a territory with oil resources may, but certainly need not, be an advantage. There are many oil rich states with low, and even very low, per capita income. Prominent examples are Nigeria and Venezuela. A major reason why richness in oil does not translate into richness of the population is the pervasive rent seeking activities induced. They may be so large that the resulting resource waste is larger than the advantage of having natural resources.

\footnotetext{
* I am grateful to the two formal discussants, Jürgen Eichberger and Wolfgang Kerber as well as to the other conference participants for helpful suggestions, and to Stephan Meier for helping to prepare the manuscript for publication.
} 
An important case of several "governments" or "nations" claiming authority over the same territory are ethnic groups. The present conflicts in ex-Yugoslavia and in the former Soviet Union, but also in Africa and in many other parts of the world, are examples. According to SINGER AND SMALL [1982], in the period 1916-1939 no less than 80 percent of the wars occurring in (what is now called) the Third World are due to ethnic conflicts leading to civil strife. After 1945, this proportion rose to 90 percent. Overall, not less than 75 percent of international wars are due to ethnic groups claiming authority over a territory.

To summarise, the quest for territories in which many governments have engaged, and still engage, is often, if not normally, a bad proposition from the point of view of society as a whole.

Federal states, in contrast, are a propitious institution, where several governments are in charge of the same territory: the central state, the provinces, states or Bundesländer, and the communes.

\section{(2) Governments Without Territory}

There are many different quasi-governmental organisations (QANGOs) which perform similar, if not the same, functions as states do.

Examples are international organisations, such as the United Nations or the International Court in Den Haag. They are made up of member countries, but they do not have any monopoly power over a territory. The number and importance of such "virtual" governments has greatly increased. There exist at least 350 intergovernmental international organisations with far more than 100'000 employees. A more extensive definition, based on the Yearbook of International Organizations lists more than 1000 intergovernmental units (see e.g. FREY [1997]).

Another case of virtual governments are religious organisations, of which the catholic church is a good example. It has a monopoly over a tiny territory in Rome, but its importance derives from a completely different source, namely the allegiance of its members. To some extent it performs similar activities to normal governments (e.g. it pursues a foreign policy) and it even raises taxes. On a much smaller scale, the "sovereign" order of Malta (it even has ambassadors in several capitals of the world) is another example. Perhaps more relevant today are sports organisations, some of which have huge resources available. An example is FIFA, the international football association. They also undertake some government-like activities (e.g. they impose rules on its 
members, they have a foreign policy, undertake development aid etc.). The same applies to cultural associations and international action groups (such as Greenpeace) unconnected to a territory.

But the most important virtual governments without territory are profit-making global firms. The more traditional ones still own plants located in specific countries, but the digital revolution has created a rapidly increasing number of knowledge firms in the New Economy. Their only capital are human resources and ideas, and they are not attached to any territory at all. Quite often, the turnover of such companies are compared to the size of the public sectors of territorial states. It turns out that only some very large countries can match the size of the largest international companies. Such firms perform governmental functions, in the sense that they influence the daily lives of its members at least as strongly as states do (e.g. they impose a language to be spoken, and rules to be followed), or they negotiate on an equal footing with national states.

The author is, of course, well aware that international organisations, churches and global firms do not meet the traditional legal definitions of a "government". These units are indeed not identical to governments. But it should also be kept in mind that the traditional definitions of government are based on the primitive notion that it is the nature of governments to have a territorial monopoly. But the purpose of this discussion is exactly to question this property from the social science and economic point of view. Taking this radically different viewpoint, it becomes clear that there are indeed multiple governments on a given territory, and governments without territory. The point was to demonstrate that, in a meaningful sense, governments need not have a territorial monopoly. Moreover, the purpose was to show that the idea of governments without monopoly is no utopia at all. Rather, the opposite is the case: increasingly, the territorial monopoly of governments is threatened by the non-territorial units identified. Thus, much of the literature on globalisation has been motivated by the fear that territorial national governments have lost significant power relative to global firms. I wish to argue that the territorial monopoly of governments is not only threatened by global firms, but by many other global actors, such as international action groups or sports associations. But, in contrast to much of the literature on globalisation, I do not see the power of territorial states vanish; rather, relative power has shifted to non-territorial governments. 
This paper advances a practical, constitutional proposal, based on the notion that there are meaningful governmental units, whose major characteristic is not the territorial extension but its function. The constitution proposal allows for the emergence of governmental organisations, which will be called FOCJ according to the acronym for "Functional, Overlapping, Competing Jurisdictions". Their territory is variable, and they do not have a territorial monopoly over it. Rather, they are in competition with other such FOCJ, and they are, moreover, exposed to political competition.

Section 2 discusses both theoretical and practical aspects of federalism, and relates them to the two types of competition just discussed. The form of federalism called FOCJ, consisting of a sophisticated network of competitive, relationships without territorial monopoly, is discussed in section 3. Section 4 deals with the strengths and section 5 with the weaknesses of FOCJ. The following section 6 refers to historical and contemporary examples of similar governmental units. Section 7 offers conclusions.

\section{Federalism and Political Competition}

The basic idea of federalism is that the preferences of individuals can better be met by decentralising government activity. The goods and services offered by government can more narrowly be geared to these demands because they differ over space due to:

- geographical and physical characteristics, e.g. between mountainous regions and planes; or between rural areas and cities;

- ethnicity, culture and traditions;

- economic structure, e.g. with respect to the share of agricultural and industrial production and services; and

- social structure, e.g. with respect to income distribution, the proportion of young families with children and retired persons.

These differences obviously lead to varying demands for public activity, e.g. with respect to the expenditures desired for education or social services. In a purely technocratic concept of politics, such spatially varied demands can be met by a centralised government. But this utterly neglects human behaviour and essentially assumes an omniscient and benevolent planner. A long time 
ago, this notion was rejected theoretically for the economy by SMITH [1776], and for society as a whole by VON HAYEK $[1960 ; 1978]$. In practice, such hubris has been demonstrated to work very badly in the case of the downfall of the Soviet nations. In the political sphere, decentralisation has clear informational advantages, because local politicians are better aware of the local needs and constraints. Even more important are the incentives motivating local political decision-makers to care for the wishes of the local population who elects them.

The Economic Theory of Federalism (see e.g. OATES [1972]; [1977], [1999]; BIRD [1993]; INMAN AND RUBINFELD [1997]) has focused on four important theoretical elements:

1. Fiscal Equivalence (OLSON [1969]; OATES [1972]; OLSON [1986]). Each jurisdiction should extend over space in such a way that the recipients of the benefits and the tax payers correspond as closely as possible. Spatial external effects - positive spillovers where nonpayers benefit from public services, and negative spillovers where outsiders are burdened with costs - are therewith avoided. The various public activities are to be attributed to the most appropriate government level.

2. Clubs (Buchanan [1965]). These are institutions offering public goods - i.e. goods from whose benefits nobody can be excluded - only to its members. The optimal size of a club is reached when the marginal utility received corresponds to the marginal cost induced by an additional member. A club thus has a limited spatial extension, and only those persons are to be admitted who are prepared to carry the marginal cost they impose.

3. Voting by Foot (TIEBOut [1956]). Competition between jurisdictions is brought about by citizens' mobility. Public jurisdictions can be considered as enterprises offering local services in return for taxes. The citizens migrate to those jurisdictions that have the most favourable relationship between services and tax prices. The induced competition forces the jurisdictions to take the citizens' wishes into account and to supply services at the lowest possible cost. The same holds for the location decision of firms.

4. Exit and Voice (HIRSCHMAN [1970]; [1993]). In addition to the possibility of choosing between the supply of various jurisdictions, citizens may also participate in the political decisions of the jurisdictions they belong to, either by voting in elections or referenda. The may moreover make themselves heard by protests, demonstrations, strikes and uprisings. Initially, exit and voice were seen as substitutes. A citizen who chooses to leave a jurisdiction 
has little incentive to take the trouble of protesting. However, the relationship may under particular conditions be complementary. Thus, when the government of the GDR had to grant exit to its citizens (via Hungary to the West) this was generally interpreted as a sign of weakness of the Communist regime. As a consequence, demonstrations were perceived to be less dangerous and more promising, and therefore grew into a mass movement (the so-called "Monday Demonstrations"), eventually forcing the resignation of the regime.

Most countries in today's world, in particular the large ones, have a federal constitution. Prominent examples are the United States and Canada in North America; Mexico, Argentina and Brazil in South America; Germany and Russia in Europe; or India in Asia. Recently, some formerly highly centralised countries such as Spain and the United Kingdom have experienced strong decentralisation tendencies. Centralised countries, such as France or the Netherlands, have become an exception, but it should also be noted that federalism has been notably undermined by the central government in many countries, examples being the United States and Germany. "Federal" countries exhibit vastly different extents of decentralisation and of competencies attributed to lower levels of the governmental organisation. For federalism to work in a satisfactory way, there are two crucial conditions to be met:

First, the sub-units must have the power to tax citizens for the functions they perform. This forces them to balance the benefits and costs of government activities. At the same time, this gives the sub-units a certain degree of independence from the central government. This requirement is not met in most "federations". As a consequence, local politicians engage in widespread rent seeking activities with the central administration. They have to please the political decision makers in the centre to obtain funds. Once granted, they have few incentives not to spend them completely, as such funds have the character of a "free good". The local politicians' rent seeking activities also encompass subsidies to cover budget deficits. Such an institutional landscape fosters fiscal irresponsibility at the local level. As this "irresponsibility" is a direct consequence of the high degree of centralisation, it does not occur when the local politicians have the competence to balance revenues and expenditures in their own jurisdiction. If it turns out that they are incapable of doing so, the citizens will throw them out of office.

This points to the second crucial condition for a well-functioning federalism. The local politicians must be elected by the citizens of their jurisdictions, and not by a larger electorate, let alone being 
appointed by the central government. This requirement aligns the politicians' incentives with the wishes of the local population.

Most presently existing federal governments do not meet these two requirements, or do so only to a small degree. They cannot attain the properties of a "civic society" with multiple horizontal networks caring for the wishes of the population. For that reason, the proposal for a new type of a federalism is advanced, which is a combination of the four aspects of federalism discussed above: (1) it meets the condition of "fiscal equivalence" by suggesting a network of multiple and overlapping governmental units; (2) it is based on well-defined members and boundaries according to the public functions to be performed, and thus is comparable to a "club"; (3) it is competitive by allowing exit and entry of members according to the "voting by foot" mechanism; and (4) it adds political competition via elections and referenda and thus includes institutions favouring "voice".

\section{A Network of Competing Jurisdictions}

The federal units here proposed are called "FOCJ" according to the acronym of its essential characteristics $^{1}$ :

- Functional $(F)$ : the new political units extend over variable areas, corresponding to the tasks or functions to be fulfilled;

- Overlapping $(O)$ : in line with the many different tasks (functions) there are corresponding governmental units extending over different geographical areas which necessarily intersect;

- Competing $(C)$ : individuals and/or communities may choose to which governmental unit they want to belong, and they have political rights to express their preferences directly via initiatives and referenda;

- Jurisdictions $(J)$ : the units established are governmental, they have enforcement power and can, in particular, levy taxes.

FOCJ form a governmental system which in an essential aspect is quite different to the one suggested in the economic theory of federalism. This theory analyses the behaviour of given 
political units at the different levels of government, while FOCJ emerge in response to the 'geography of problems'. ${ }^{2}$

The four elements of FOCJ are now discussed in more detail.

\section{A. Functions}

A particular public service that benefits a certain geographical area should be financed by the people living in that area, i.e. there should be no spill-overs. The different governmental units can cater for differences in the populations' preferences or, more precisely, to the citizenry's demands. To minimise cost, these units have to exploit economies of scale in production. As the latter may strongly differ between functions (e.g., between schools, police, hospitals, power plants and defence) there is an additional reason for uni-functional (or few-functional) governmental units of different sizes. This endogeneity of the extension of the governmental units constitutes an essential part of FOCJ.

\section{B. Overlaps}

FOCJ may overlap in two respects: (i) FOCJ catering to different functions may intersect; (ii) two or more FOCJ catering even for the same function may geographically intersect (e.g., a multitude of school FOCJ may exist in the same geographical area). An individual or a political community normally belongs to various FOCJ at the same time. FOCJ need not be physically contiguous, and they need not have a monopoly over a certain area of land. Thus, this concept completely differs from archaic nationalism with its fighting over pieces of land. It also breaks with the notion of federalist theory that units at the same level may not overlap.

\section{Competition}

The heads of FOCJ are induced to conform closely to their members' preferences by two mechanisms: while the individuals' and communities' possibilities to exit mimics market

\footnotetext{
1 The concept is the result of joint work with Reiner Eichenberger. See FREY AND EICHENBERGER [1995], [1996], [1999].

2 The general idea of FOCJ may be found in MONTESQUIEU [1749]. BURNHEIM [1985] also discusses several elements. In economics, a related idea has been suggested by TULLOCK [1994]. CASELLA AND FREY [1992] discuss the concept and refer to relevant literature. THE CENTRE FOR ECONOMIC POLICY RESEARCH [1995] develops the idea of flexible integration, where all the members of the future EU would have to participate in a 'common base' comprising the four freedoms as well as the transfer programs, and may opt to enter 'open partnerships'.
} 
competition, their right to vote establishes political competition. It should be noted that migration is only one means of exit; often, membership in a particular FOCUS (this is the singular of FOCJ) can be discontinued without changing one's location. Exit is not restricted to individuals or firms; political communities as a whole, or parts of them may also exercise this option. Moreover, exit may be total or only partial. In the latter case, an individual or community only participates in a restricted set of FOCUS activities.

For FOCJ to establish competition between governments, exit should be as little restrained as possible. In contrast, entry need not necessarily be free. As for individuals in Buchanan-type clubs, jurisdictions and individuals may be asked a price if they want to join a particular FOCUS and benefit from its public goods. The existing members of the particular FOCUS have to democratically decide whether a new member pays an adequate entry price and thus is welcome.

Competition also needs to be furthered by political institutions, as the exit option does not suffice to induce governments to act efficiently. The citizens should directly elect the persons managing the FOCJ, and should be given the right to initiate popular referenda on specific issues. These democratic institutions are known to raise efficiency in the sense of meeting individual preferences (for elections, see Downs [1957], MuELLER [1989], for referenda CRONIN [1989], FREY [1994]).

\section{Jurisdictions}

A FOCUS is a democratic governmental unit with authority over its citizens, including the power to tax. According to the two types of overlap, two forms of membership can be distinguished: (i) The lowest political unit (normally the community), and all corresponding citizens automatically become citizens of the FOCJ to which their community belongs. In that case, an individual can only exit via mobility. (ii) Individuals may freely choose whether they want to belong to a particular FOCUS but, while they are its citizen, they are subject to its authority. Such FOCJ may be non-voluntary in the sense that one must belong to a FOCUS providing for a certain function, e.g., to a school-FOCUS, and must pay the corresponding taxes. An analogy here is health insurance, which in many countries is obligatory, but where individuals are allowed to choose an insurance company. The citizens of such a school-FOCUS may then decide that everyone must pay taxes in order to finance a particular school, irrespective of whether one has children. With respect to FOCJ providing functions with significant redistributive effects, a minimal regulation by the central government may grant that, e.g., citizens without children do not join 'school- 
FOCJ' which in effect do not offer any schooling and therefore have correspondingly low (or zero) taxes.

\section{Strengths of FOCJ}

FOCJ compare favourably to traditional forms of federalism with respect to the governments' incentives and possibilities to satisfy heterogeneous preferences of individuals. Due to the concentration on one functional area, the citizens of a particular FOCUS have better information on its activity, and are in a better position to compare its performance to other governments. As many benefits and costs extend over a quite limited geographic area, we envisage FOCJ to be often small, which is also helpful for voters' evaluations. The exit option opened by the existence of overlapping jurisdictions is also an important means to make one's preferences known to governmental suppliers.

FOCJ are moreover able to provide public services at low cost, because they are formed in order to minimise inter-jurisdictional spill-overs and to exploit economies of scale. When the benefits of a specific activity indivisibly extend over large areas, and there are decreasing costs, the corresponding optimal FOCUS may cover many communities, several nations, or even Europe as a whole. Defence against outward aggression may be an example where the appropriate FOCUS may extend over the whole of Europe (even beyond the European Union).

The threat of dissatisfied citizens or communities to exit the FOCUS, and the benefit of new citizens and communities joining, gives the politicians in charge an incentive to take the preferences of the citizens into account and to provide the public services efficiently. FOCJ may also break up the politicians' cartel to competent outsiders. While all-purpose jurisdictions attract persons with broad and non-specialised knowledge to become politicians, in FOCJ persons with a well-grounded knowledge in a particular functional area (say education or refuse collection) are successful.

A federal web composed of FOCJ certainly affects the role of the nation-states. They will certainly lose functions they presently do not fulfil according to the population's preferences, or which they produce at higher cost than FOCJ designed to exploit cost advantages. On the other hand, the scheme does not purport to do away with nations, but allows for multi-national, as well as small scale, alternatives where they are desired by the citizens. Nation-states subsist in so far as they provide functions efficiently according to the voters' preferences. 


\section{Alleged Disadvantages of FOCJ}

The following four weaknesses are often advanced against the concept of FOCJ.

Overburdened Citizens. In a federal system of FOCJ, each individual is a citizen of various jurisdictions. As a consequence, individuals may be overburdened by voting in elections and referenda taking place in each FOCUS. However, citizens in a direct-democratic FOCUS find it much easier to politically participate, as they have only to assess one or a few concrete issues at a time.

Overburdened Consumers. An individual is confronted with a multitude of suppliers of public services, which arguably makes life difficult. This is the logical consequence of having more options to choose from, and is similar to supply in the private sector. If citizens find it to be a problem, a governmental or a private advisory service can be established, which offers information and support for the consumers' decisions.

'Need' to Coordinate the Activities of FOCJ. While co-ordination is obviously often needed, coordination between governments is not a good measure by itself. It sometimes serves to build cartels among the members of the 'classe politique' who then evade or even exploit the population's wishes (see CEPR [1993], VAUBEL [1994], FREY [1994]). As far as welfare increasing co-ordination is concerned, its need is reduced because the FOCJ emerge in order to minimise externalities. If major spill-overs between FOCJ exist, new FOCJ will be established by the citizens taking care of these externalities.

Redistribution. It has often been claimed that all forms of federalism - including FOCJ undermine redistributional policies. This fear is unwarranted, as the citizens still can express their solidarity towards persons with low income (in particular by establishing a FOCUS designed for redistribution). Moreover, they can still undertake redistribution to insure themselves against future loss of income. Only as far as redistribution is a pure public good, and thus must be enforced to prevent free-riding, may a problem arise. Recent empirical research (GOLD [1991], KIRCHGÄSSNER AND POMMEREHNE [1996]), however, suggests that substantial redistribution is feasible in federal systems.

\section{Examples of FOCJ in History and Today}


Decentralised, overlapping political units have been an important feature of European history. The competition between governments in the Holy Roman Empire of German Nations, especially in today's Italy and Germany, has been intensive. Many of these governments were of small size. Some scholars attribute the rise of Europe to this diversity and competition of governmental units which fostered technical, economic and artistic innovation (see, e.g., HAYEK [1960], JONES [1987], WEEDE [1993]). While the Chinese were more advanced in many respects, their superiority ended with the establishment of a centralised Chinese Empire (PAK [1995], ROSENBERG AND BIRDZELL [1986]). The unification of Italy and Germany in the 19th century, which has often been praised as a major advance, partially ended this stimulating competition between governments and led to deadly struggles between nation states. Some smaller states evaded unification; Liechtenstein, Luxembourg, Monaco, San Marino and Switzerland stayed politically independent, and at the same time grew rich.

The above-mentioned governmental units were not FOCJ in the sense outlined in this contribution, but they shared the characteristic of competing for labour and capital (including artistic capital) among each other. However, history also reveals examples of jurisdictions close to FOCJ. The problems connected with Poland's strong ethnic and religious diversity (Catholics, Protestants and Jews) were at least partly overcome by jurisdictions organised along these features, and not according to geographical boundaries (see RHODE [1960] and HAUMANN [1991]). The highly successful Hanse prospered from the 12th to the 16th century, and comprised inter alia Lübeck, Bremen, Köln (today German), Stettin and Danzig (today Polish), Kaliningrad (today Russian), Riga, Reval and Dorpat (today parts of the Baltic republics) and Groningen and Deventer (today Dutch); furthermore, London (England), Bruges and Antwerp (today Belgian) and Novgorod (today Russian) were Handelskontore or associated members. It was clearly a functional governmental unit providing for trade rules and facilities and was not geographically contiguous.

In two countries, functional, overlapping and competing jurisdictions exist (but they do not in all cases meet all the requirements of FOCJ specified above).

In the United States, special districts play a significant role in the American federalist system, and their number has substantially increased over the last decades. While some of the special districts are dependent, others are both autonomous and democratically organised. According to empirical research (MEHAY [1984]), the latter type is significantly more efficient. Not 
surprisingly, existing municipalities make an effort to prevent the emergence of these more efficient governmental units. Thus, for example, in various states a minimum population size is required and various administrative restrictions are imposed.

In Switzerland, a multitude of governmental units exist, some of which come close to FOCJ. In addition to the 26 cantons, there are roughly 8,000 communes of various forms. The most important are the 2,940 political communes which define citizenship (i.e. a Swiss is not citizen of the nation but of a political commune). These communes have considerable autonomy, in particular they have wide-ranging authority to impose income and property taxes. As a consequence, the tax rates between neighbouring political communes may strongly differ - a factor inducing political competition between communes, and bundles of public services and taxes favorable to the citizens. In addition to political communes, there are roughly 5,000 overlapping, functional special communes. The most important are school communes offering education for the children of one or several political communes. They are public jurisdictions levying their own taxes, whose rate is determined by a citizens' meeting. Other functional, democratic, and overlapping communes are those established by the protestant and catholic churches. A citizen may freely choose to which one he or she desires to belong, but once a member, one has to pay an appropriate tax. In addition to these and other types of communes, there are many thousands of "communal units" ("Gemeindeverbände" or "Zweckverbände") founded by the communes to deal with specific tasks such as canalisation, hospitals, old people's homes or refuse collection. These units have, however, no independent power to tax and there are rarely direct participation rights by the citizens. This short discussion of the Swiss federal system at the local level (see more extensively DE SPINDLER [1998]) shows that FOCJ are a practical possibility, but that they have not yet been developed to their full extent.

A completely different kind of FOCJ develops in Cyperspace. An example is the Internet Corporation for Assigned Names and Numbers (ICANN), the body that now administers Internet domain names. ${ }^{3}$ It could well evolve into a global regulation institution without any territorial boundaries. While laws that govern business conduct are primarily country-specific, the Internet acknowledges no such geographic borders, and net firms can move from one jurisdiction to another by switching the location of their servers. ICANN is not a governmental institution (though it was initiated by the US government); it is based on openness and collaboration rather 
than closed procedural regulation. It seeks to establish wider legitimacy by holding democratic elections, relies on voluntary dispute-resolution channels, and adapts its policy to rapidly changing technology. This new kind of Cyperspace body thus has several features of FOCJ: it is functional and overlapping; it allows exit and entry and establishes democratic accountability; and it imposes prices (taxes) for its services. It is much closer to the idea of FOCJ developed here than to traditional forms of government.

\section{Conclusions}

In view of the major advantages of FOCJ, the economist's standard question arises: if this type of federalism is so good, why is it not more successful?

The organisation of states today does not follow the model of FOCJ for two major reasons. An obvious, but crucial one, is that individuals and communities are prohibited from establishing such jurisdictions, and in many countries of the European Union, communities are not even allowed to formally collaborate with each other without the consent of the central government (see SHARPE [1993]).

Secondly, FOCJ violate the interests of politicians and public officials at higher levels of government. FOCJ reduce the public suppliers' power and increases citizens' influence by the newly introduced mechanisms of competition by exit and entry, and by direct democratic elements. Both are regularly opposed by the politicians in power.

A federal system of FOCJ will not arise if these barriers are not overcome. A necessary condition are new constitutional rules, allowing the formation of FOCJ and giving the citizens and the governments the right to appeal to the Constitutional Court if they are blocked.

Functional, Overlapping and Competing Jurisdictions break with the ingrained notion that governments must have a well-defined territorial monopoly. The constitutional proposal advanced here is not utopian, but is in line with the emergence of virtual governments witnessed over the recent past.

\footnotetext{
${ }^{3}$ I am grateful to Lawrence Lessig for drawing my attention to this institution. See http://www.icann.org and ENGEL [1999] for a general discussion of legal and political aspects of the Internet.
} 


\section{References}

BIRD, R. M. [1993], "Threading the Fiscal Labyrinth: Some Issues in Fiscal Decentralization", National Tax Journal, 46, 201-221.

Breton, A. [1996], Competitive Governments. An Economic Theory of Politics and Public Choice Finance, Cambridge University Press: New York.

Buchanan, J. M. [1965], "An Economic Theory of Clubs", Economica, 32, 1-14.

BurnheIM, J. [1985], Is Democracy Possible?: The Alternative to Electoral Politics, Polity Press: Cambridge.

Casella, A. And B. S. Frey [1992], "Federalism and Clubs: Towards an Economic Theory of Overlapping Political Jurisdictions", European Economic Review 36, 639-646.

Centre for ECONOMic Policy Research (CEPR) [1993], Making Sense of Subsidiarity: How Much Centralization for Europe? CEPR: London.

Centre for ECONOMic Policy Research (CEPR) [1995], Flexible Integration. Towards a More Effective and Democratic Europe, CEPR: London.

Cronin, T. E. [1989], Direct Democracy. The Politics of Initiative, Referendum and Recall, Harvard University Press: Cambridge, MA.

DE SPINDLER, J. [1998], FOCJ. Ein Konzept zur Neuordnung der Zusammenarbeit öffentlicher Gebietskörperschaften, Haupt: Bern.

Downs, A. [1957], An Economic Theory of Democracy, Harper and Row: New York.

ENGEL, C. [1999], The Internet and the Nation State, Lectiones Jenenses, Max-Planck-Institute for Research into Economic Systems: Jena.

FREY, B.S. [1997], "The Public Choice of International Organizations", in: D.C. Mueller (ed.), Perspectives on Public Choice: A Handbook, Cambridge University Press: Cambridge: Cambridge, 106-123.

FREY, B. S. [1994], "Direct Democracy: Politico-Economic Lessons from Swiss Experience", American Economic Review, 84, 338-348. 
Frey, B. S. AND R. EICHENBERGER [1995], "Competition among Jurisdictions. The Idea of FOCJ", In: Lüder Gerken (ed.) Competition among Jurisdictions, MacMillan: London, 209229.

FREY, B. S. AND R. EICHENBERGER [1996], "FOCJ:Competitive Governments for Europe", International Review of Public Economics, 16, 315-327.

Frey, B. S. AND R. EICHENBERGER [1999], The New Democratic Federalism for Europe: Functional Overlapping and Competing Jurisdictions, Edward Elgar: Cheltenham.

GoLD, S. D. [1991], "Interstate Competition and State Personal Income-Tax Policy in the 1980s", In: Daphne A. Kenyon and John Kincaid (eds) Competition among States and Local Governments, Urban Institute Press: Washington DC, 205-217.

Haumann, H. [1990], Geschichte der Ostjuden, Deutscher Taschenbuch-Verlag: München.

HAYEK, F. A. VON [1960], The Constitution of Liberty, Routledge: London.

HAYeK, F. A. VON [1978], "Competition as Discovery Procedure", In: F. A. Hayek (ed.) New Studies in Philosophy, Politics, Economics and the History of Ideas, Routledge and Kegan: London, 119-130.

Hirschman, A. O. [1970], Exit, Voice and Loyality, Harvard University Press: Cambridge, MA.

Hirschman, A. O. [1993], "Exit, Voice, and the Fate of the German Democratic Republic", World Politics, 45, 173-202.

InMAn, R. P. And D. Rubinfeld [1997], "The Political Economy of Federalism", In: Dennis C. Mueller (ed.) Perspectives on Public Choice: A Handbook, Cambridge University Press: Cambridge, 73-105.

JONES, E. L. [1987], The European Miracle, 2nd edn., CUP: Cambridge.

Kirchgässner, G. AND W. W. Pommerehne [1996], "Tax Harmonization and Tax Competition in the European Community: Lessons from Switzerland", Journal of Public Economics, 60, 351-371.

Menay, S. L. [1984], "The Effect of Governmental Structure on Special District Expenditures", Public Choice, 444, 339-348.

Montesquieu, C. L. [1749], De l'esprit des lois, Garnier: Paris. 
Mueller, D. C. [1989], Public Choice II, Cambridge University Press: Cambridge.

OATES, W. E. [1972], Fiscal Federalism, Harcourt Brace Jovanovich: New York.

OATES, W. E. (ed.) [1977], The Political Economy of Fiscal Federalism, Lexington Books: Lexington, MA.

OATES, W. E. [1999], "An Essay on Fiscal Federalism", Journal of Economic Perspectives, 37, 1120-49.

Olson, M. [1969], "The Principle of "Fiscal Equivalence": The Division of Responsibilities among Different Levels of Government", American Economic Review, 59, 479-487.

OLson, M. [1986], "Towards a More General Theory of Governmental Structure", American Economic, Papers and Proceedings, 76, 120-125.

PAK, H. M. [1995], "Effective Competition, Institutional Choice and Economic Development of Imperial China", Kyklos, 48, 87-103.

RHODE, G. [1960], "Staaten-Union und Adelsstaat: Zur Entwicklung von Staatsdenken und Staatsgestaltung in Osteuropa, vor allem in Polen/Litauen, im 16. Jahrhundert", Zeitschrift für Ostforschung, 9, 185-215.

Rosenberg, N. AND L. E. Birdzell [1986], How the West Grew Rich. The Economic Transformation of the Industrial World, I.B. Tauris: London.

SCHumpeter, J. A. [1942], Capitalism, Socialism and Democracy, 1st edn, Harper: New York.

SHARPE, L. J. (ed.) [1993], The Rise of Modern Government in Europe, Sage: London.

Smith, A. [1776], An Inquiry into the Nature and Causes of the Wealth of Nations, Reprinted 1980, Deut \& Sane Ltd: London.

Tiebout, C. M. [1956], "A Pure Theory of Local Expenditure", Journal of Political Economy, 64, 416-424.

TuLLOCK, G. [1994], The New Federalist, Fraser Institute: Vancouver.

VAubeL, R. [1994], "The Political Economy of Centralization and the European Community", Public Choice, 81, 151-190.

WeEDE, E. [1993], "The Impact of Interstate Conflict on Revolutionary Change and Individual Freedom", Kyklos, 46, 473-495. 
Prof. Bruno S. Frey

Institute for Empirical Economic Research

University of Zurich

Blümlisalpstrasse 10

CH-8006 Zurich

Switzerland

Tel: ++41-1-634 37 30/31

Fax: ++41-1-634 4907

E-mail: bsfrey@iew.unizh.ch 